\title{
THE ROLE OF PARENTS IN FINANCIAL LITERACY OF YOUNG PEOPLE
}

\author{
BEATA ŚWIECKA \\ University of Szczecin, POLAND \\ email: beata.swiecka@wzieu.pl
}

\author{
RECEIVED \\ 20 April 2018 \\ ACCEPTED \\ 12 July 2018 \\ JEL \\ CLASSIFICATION \\ D10, D14, D18, G20, I22
}

KEYWORDS financial literacy, young people, financial education, parents, personal finance

ABSTRACT This article presents an overview of the financial literacy of the 15 years old students. The aim of the article is to present conceptualization of financial literacy and the results of own research on the financial literacy of young people in Poland on the background of secondary research. For the purposes of the article, was formulated a thesis: parents play a large role in increasing financial literacy of young people. Data obtained as part of the primary survey was carried out as part of a grant from the Polish-German Foundation for Science "Education and financial literacy in Germany and in Poland. Transfer of knowledge, analysis and recommendations" (No. 2017-03), implemented by the University of Szczecin (project leader), Society for Promotion of Financial Education in Gdynia and social science research institute GP Forschungsgruppe - Institut für Grundlagen und Programmforschung from Berlin. Own Survey they were done in the fourth quarter of 2017 on a nationwide representative sample of 2070 respondents, aged 15. The research was carried out using the PAPI method.

\section{Introduction}

The European Parliament has recognized that the increase of consumers' financial literacy improves the functioning of financial mechanisms on the market. In line with the European Parliament's guidelines, raising the level of consumer financial literacy should be a priority for decision-makers at both Member State and European level, not only for the benefit of individuals but also for the benefit of society and the economy. Particular attention 
has been a focus on the educational needs of young consumers who must make decisions affecting their economy. (European Union, 2008). These statements show the importance of financial literacy and financial education in the microscale from the point of view of an individual, as well as a mezzo or a financial institution, as well as macro, i.e. the economy on a national and international scale. Considering the significance of financial literacy, which is important at the global level as well as the individual level, an attempt was made to analyze financial literacy issues. It is not without reason that an analysis has been made of a specific group of subjects - young people who if they will master in personal finances will have greater financial skills as adults. The aim of the article is a conceptualization of financial literacy and presentation of the results of a primary survey on the financial literacy of young people in Poland, on the background secondary survey. For the article, was formulated a thesis, that parents play a large role in increasing financial literacy of young people.

To achieve the goal was used the method of desk research and the results of primary research and the background secondary research. Data obtained as part of the primary survey was carried out as part of a grant from the Polish-German Foundation for Science "Education and financial literacy in Germany and in Poland. Transfer of knowledge, analysis and recommendations "(No. 2017-03), implemented by the University of Szczecin (project leader), Society for Promotion of Financial Education in Gdynia and social science research institute GP Forschungsgruppe - Institut für Grundlagen und Programmforschung from Berlin. The primary survey was carried out in the fourth quarter of 2017 on a nationwide representative sample of 2070 respondents The research was carried out using the PAPI method.

\section{Conceptualization of financial literacy literature review}

Financial literacy is a significant problem studied both in Poland and abroad. The definition of this concept was taken largely by the OECD, which introduced the concept of financial literacy as one of the first. According to OECD (INFE) "financial literacy is a combination of awareness, knowledge, skills, attitude, and behavior necessary to make sound financial decisions and ultimately achieve individual wellbeing (Atkinson, Messy, 2012). This definition is now globally acknowledged and was also endorsed by $G 20$ leaders in 2012 (G20, 2012). The definition clear that financial literacy is more than knowledge, it also includes attitudes, behavior, and skills It stresses the importance of decision making - applying knowledge and skills to real-life process - and indicates that the impact should be improved financial wellbeing"(Atkinson, Messy, 2012). According the PISA (2017) "financial literacy is knowledge and understanding of financial concepts and risk, and the skills, motivation, and confidence to apply such knowledge and understanding in order effective decisions across a range of financial contexts, to improve the financial well-being of individual and society, and to enable participation in economic life. The definition, like other of PISA domains, has two parts. The first refers to the kinds of thinking and behavior the characteristic the domain. The second part refers to the importance of developing the particular literacy. In PISA "literacy" refers not only to the capacity of 15-years-old students to apply knowledge and skills in a key subject but also to students' ability to analyze, reason and communicate as they pose, solve and interpret problem in a variety of situations (PISA, 2017).

The largest international survey of young people (15-years old students) conducted in the world as well as in Poland is the PISA (Program for International Student Assessment). It is implemented by an international consortium overseen by OECD and representatives of member countries. It is the largest international financial literacy study of 15 -years old students in the world. It has been implemented every 3 years since 2000 in all OECD countries, as well as in dozens of partner countries, however, the financial literacy research was carried out for the first time in 
2012. Poland has participated in the PISA survey from the beginning, that is from 2000 . The financial literacy study implemented in 2012 was conducted among 29,000 15-year-olds from 13 OECD countries (Table 1). The aim of the study was to check whether 15-year-olds (in many countries in this age are completing compulsory education) have the knowledge and skills to continue to live in their lives. Details on the financial literacy research made in 2012 and 2015, as well as planned in 2018, are presented in Table 1.

Table 1. Financial literacy in PISA Survey (the biggest international research)

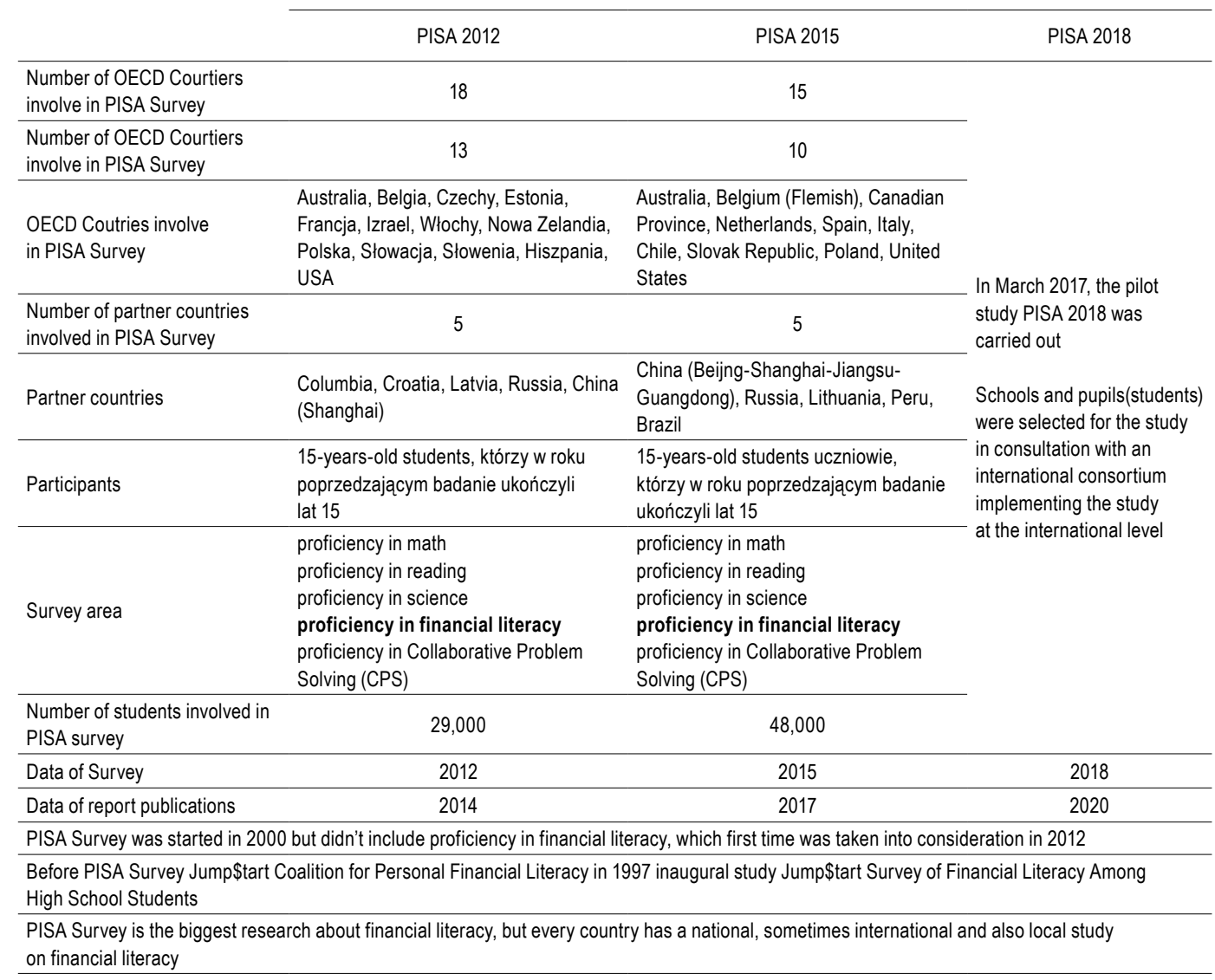

Source: own study based on PISA $(2017,2014)$.

In Poland national range studies are conducted (NBP, Kronenberg, SKEF, ING Barometer, etc.). The biggest weakness of the conducting survey is the incomparability of their results. This makes it impossible to apply for completed surveys for more sophisticated projects. There are also international studies that are not conducted on such a large scale as the PISA survey and are usually not carried out cyclically. Due to the size of the study (48,000 respondents), as well as the cyclicality (two studies for the time being and the third study planned for 2018) is present the PISA survey. 
According to PISA 2015 (PISA, 2017) Polish 15 - years old students scored significantly fewer points than in the previous study carried out in 2012 (published in 2015). According to PISA 2015 (PISA, 2017), Polish 15-yearolds scored 485 points (in PISA 2012 - 510 points) and this time they were below the OECD average, which in the PISA 2015 survey was 489 points. Not much under the line, but still below average. In 2015, the Chinese scored the most points - 566 points (in 2012 - 603 points), and Belgians - 541, both in 2015 and in 2012. In 2012, lower results than Poland had: USA, Russia, France, Slovenia, Spain, Croatia, Israel, Slovakia, Italy, and Colombia (PISA, 2014, p. 32). At the next survey, in 2015 most of these countries, which had lower results, were ahead of Poland, including Russia (512 points) and the USA (587 points). The following countries had lower results than Poland: Italy, Spain, Lithuania, Slovak Republic, Chile, Peru, Brazil (PISA, 2017).

The PISA is a study of 15 -year-old - students who completed the age of 15 in the year preceding the survey. In 2012, they were pupils from the year 1996, and the study in 2015 covered people born in 1999. In each edition of PISA, they have checked three skills: reading and interpretation, solving mathematical problems and reasoning in natural sciences. Since 2012, the PISA survey has been extended to include an additional component - financial literacy. The inclusion of the financial literacy component in the PISA survey was the result of previous work that lasted since 2005 when the OECD published a report highlighting the serious lack of financial knowledge in many countries around the world (PISA, 2017, 2014). In 2008, the OECD created the International Network on Financial Education (INFE) to reach out-of-OECD countries in information sharing and data collection in key areas of financial education. Due to the lack of data on OECD financial knowledge and skills, INFE took into consideration the financial literacy measurements in the PISA study (Lusardi 2015, p. 640). In PISA (2014), research on financial literacy was presented for the first time. These were studies carried out in 2012. Subsequent PISA surveys (2017) were published in 2017 and implemented in 2015. The PISA (2017, p. 15) financial literacy rating provides a picture of 15-year olds' ability to apply their accumulated financial knowledge and skills to real- life situation issuing a financial issue and decisions. PISA (2014) was implemented in 2012 in 13 OECD countries and PISA (2017) in 2015 in 15 OECD countries. OECD countries, 22\% of 15 -years old students - or more than 1.2 million of them have a baseline level of proficiency in financial literacy (level 2). Students of this level can recognize the difference between the needs and wants, such as an invoice. Some of the $12 \%$ of young people score at level 5 - the highest level of proficiency. These teens make complex financial decisions. They can describe the potential financial landscape, such as income tax.

\section{Financial literacy in primary (own) research}

The supplements of PISA survey is primary research carried out as part of the grant from the Polish-German Foundation for Science " Education and financial literacy in Germany and in Poland. Transfer of knowledge, analysis and recommendations "(No. 2017-03), implemented by the University of Szczecin (project leader), Society for Promotion of Financial Education in Gdynia and social science research institute GP Forschungsgruppe Institut für Grundlagen und Programmforschung from Berlin. The survey was done in the fourth quarter of 2017 on a nationwide representative sample of 2070 respondents, aged 15 (age - accordance with the PISA methodology). The study was conducted using the PAPI method.

The structure analysis in primary (own) survey shows that young people mostly $(75 \%)$ learn about financial matters from their parents. School plays a much smaller role than the internet. More than half of them $(56 \%)$ regularly receive money from their parents. It is interesting that $11.1 \%$ are already earning their money. It is not 
a large percentage, but for such a young age, it is not too little. It would be helpful to have specific questions that would refer to the regularity of the taken on intentions, type of activity, intentionality. One of the financial decisions is indebtedness. It would seem that young people do not have or should not have any debt at 15 age. The own study shows that almost $15 \%$ have debt. This result is worrying. The survey shows that $9.5 \%$ are indebted to friends, $4.7 \%$ to parents, and $0.5 \%$ are in default for telephone charges. In the case of an indebtedness to friends and family, we can also ask additional questions: is it indebted unilaterally or is it notorious? Undoubtedly, the exploration of these question would be helpful in answering the questions of how the situation in the sphere of debt of young people really looks like. Having a young people financial problems, they rely mainly on their parents and family. It's up to them with financial problems but also learns financial management from them. In finance education, the school plays a small and even marginal role. From the school young people expect practical knowledge, a large number of examples, interesting form of knowledge transfer. The own survey shows that young people they want to know how to keep expenses low, about the rules of the household budget, and also interested in saving opportunities. They have known how to withdraw cash from an ATM, how to pay with a card, but a little knowledge how to open a bank account on the internet. In terms of consumption decisions, in the first place, the money is spent on clothing and sweets. In terms of saving decisions, they largely store money in cash at home, giving as a reason convenience. The money they spend is mainly spent on pleasure, but they also think about being financially independent, having funds for unforeseen expenses, when parents do not want to pay it. In the operational activity associated with the opening account, parents play a large role. They are the first to inform children about this possibility. At the age of 15-years old student got a money from family, especially from parents (Figure 1).

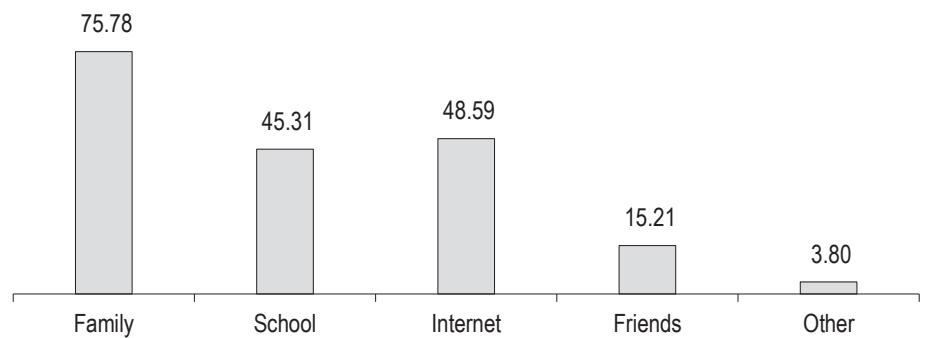

Figure 1. Where do you find information about financial matters? (\%)

Source: own study.

Data on the figure show that parents have a leading role in financial matters (Figure 1). Young people have information about finance from parents, who are the first who give advice when children have a problem in financial area (Figure 2), and also parents are the main donors of money (Figure 3). The role of parents in the field of finance for young people is indispensable. At the age of 15 , young people who do not have much opportunity to learn about finance at school are looking for information from their parents. In particular, they are interested in how to earn money, where it is possible find a job, how many years they have must, if they what to start working, how many hours they can work, what they need to start work, and other. Figure 4 shows that over 40\% (43.1\%) of respondents would like to know where and how to set up an account, which means that such a large percentage does not know it yet. 
Assuming that an open account is the first level of financial inclusion. If they do not have an account yet, they do not know about payment cards, electronic banking, mobile payments, etc. So they do not have knowledge of finances that enable current functioning. Lack of this knowledge also points to deficiencies in saving and debt opportunities.

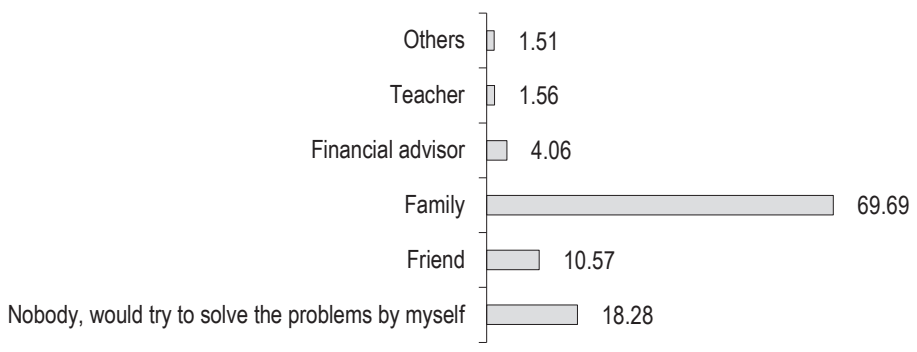

Figure 2. Whom would you ask for advice if you had financial problems? (\%)

Source: own study.

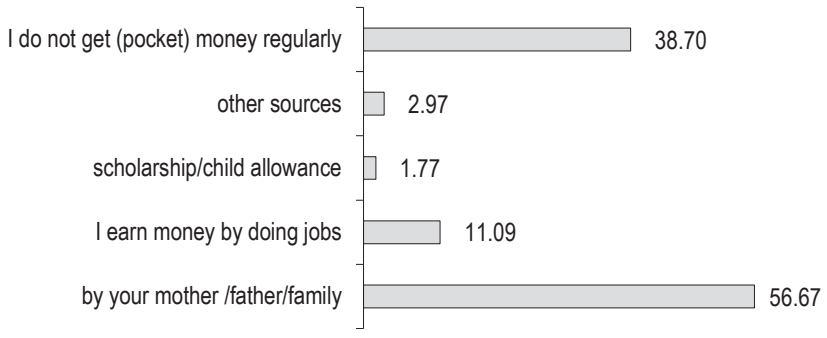

Figure 3. Are you getting regularly (pocket) money? (\%)

Source: own study.

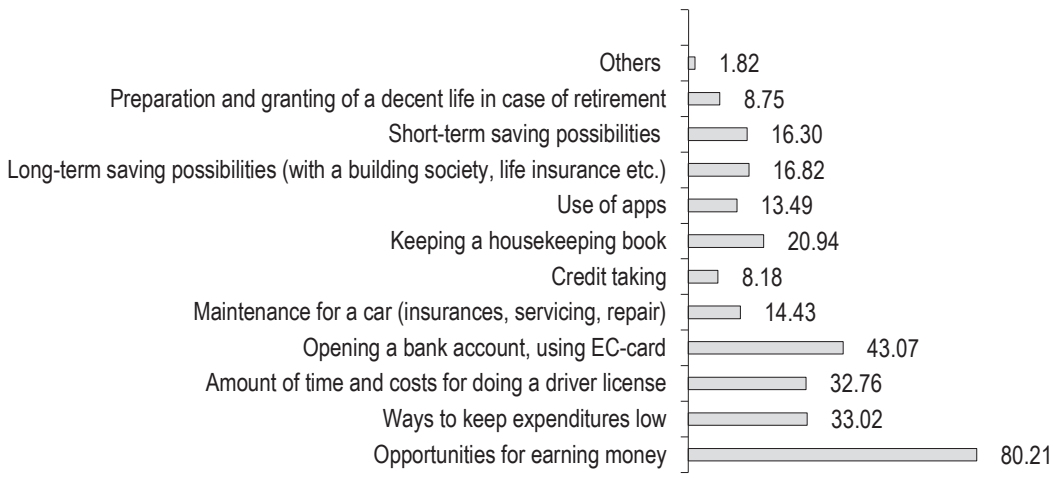

Figure 4. Which kind of information do students in your age need most? (\%)

Source: own study. 


\section{Conclusions}

The low level of financial literacy 15-years old students are a results in the inability to obtain financial knowledge at school, which received a small piece of finance in the elementary school (on the lecture Knowledge about Society). Young people receive more detailed knowledge in the first year of secondary school on the lecture "Basics of entrepreneurship" and "Economics in practice", which according to the new program was cancel from the schools. The knowledge acquired by the students at school is poor, therefore the parents are the main source of information about financial aspects: financial management, bank accounts, payment cards, earning opportunities and banking services. Primary research shows that a large role in increasing financial literacy and financial education for 15 years old students have parents. Parents are the main source of financial knowledge, parents mainly give children money, and they come to parents when they have financial problems. School at 15 years of students plays a secondary role. Importance role of a parent was confirmed by research. However, the knowledge of parents is often not satisfied, and children need a school as a medium in the transfer of practical knowledge of finance, which should be an obligatory and not only optional. At this stage, the question arises: who should play a greater role in the financial education of young people: school or parents? To what extent does the school and in which parents? In which areas should be complemented, and in which to strengthen. These are questions that need to be explored for complementary action to increase the financial literacy of young people.

\section{References}

Anagol, S, Cole, S, Sarkar, S. (2012). Understanding the incentives of commissions motivated agents: theory and evidence from the Indian life insurance market. Working Papers 12-055. Harvard Business School.

Atkinson, A., Messy, F. (2011). Assessing financial literacy in 12 countries. An OECD pilot exercise. Netspar Discussion Paper 01/2011014, Network for Studies on Pension, Aging and Retirement. Paris.

Atkinson, A. Messy, F. (2012). Measuring financial literacy. Results of the OECD/International Network on Financial Education (INFE) Pilot Study. OECD Working Papers on Finance, Insurance and Private Pensions, No. 15, OECD Publishing.

European Union (2008). Improving consumer education and awareness on credit and finance. European Parliament resolution of 18 November 2008 on protecting the consumer: improving consumer education and awareness on credit and finance (2007/2288(INI), P6_TA(2008) 0539, Strasbourg.

Financial education for youth. The role of schools (2014). Paris OECD, April.

Financial education and financial literacy for youth in Germany and Poland. Transfer of knowledge, analysis, and recommendation (2018). Results of a primary survey from grant Science Polish-German Foundation (No. 2017-03), B. Świecka (head of grants), University of Szczecin.

Hastings, J., Madrian, B., Skimmyhorn, W. (2012). Financial literacy, Financial education and economic outcomes. NBER Working Paper No. 18412 September.

INFE (2015). National strategies for financial education. OECD/INFE Policy Handbook, OECD, November.

Lusardi, A. (2015). Financial literacy skills for the 21st Century: Evidence from PISA. The Journal of Consumer Affairs, 3 (49).

Lusardi, A. (2011). Survey of the States: economic and personal finance education in our nation's schools. Council Econ. Educ.

Measuring financial literacy (2011). Core questionnaire in measuring financial Literacy. Questionnaire and Guidance Notes for conducting an Internationally comparable survey of financial literacy. OECD INFE, Paris.

OECD (2009). Framework for the development of financial literacy baseline surveys: A first international comparative analysis. OECD Working Papers on Finance, Insurance and Private Pensions, No. 1. Paris: OECD Publishing.

PISA (2017). PISA 2015 Results. Students financial literacy (Volume IV). Programme for International Student Assessment, OECD Publishing.

PISA (2014). PISA 2012 Results: Students and Money: Financial Literacy Skills for the 21st Century (Volume VI). Programme for International Student Assessment, OECD Publishing. 
INFE (2011). Measuring Financial Literacy. Core Questionnaire in Measuring Financial Literacy: Questionnaire and Guidance Notes for conducting an Internationally Comparable Survey of Financial Literacy. Paris: OECD.

NFEC (2014). Financial literacy solutions. National Financial Educators Council. Retrieved from: http://www.financialeducatorscouncil. org/financial-literacy-definition.html.

OECD/INFE (2015). National strategies for financial education. OECD/INFE Policy Handbook. Paris: OECD.

Xiao, J. (2016). Handbook of consumer finance research. Second Edition, Springer.

Cite this anticle aS: Świecka, B. (2018). The role of parents in financial literacy of young people. European Journal of Service Management, 3 (27/1), 313-320. DOI: 10.18276/ejsm.2018.27/1-40. 